\title{
Pacific Atoll Living: How Long Already and Until When?
}

William R. Dickinson, Dept. of Geosciences, University of Arizona, Tucson, Arizona 85721, USA; wrdickin@dakotacom.net.

\section{ABSTRACT}

Modern atoll reefs began to grow after rising postglacial eustatic sea level overtopped degraded carbonate platforms that had been exposed as subaerial limestone plateaus during synglacial drawdowns in sea level. Stable atoll islets atop emergent paleoreef flats did not begin to develop until after the mid-Holocene hydro-isostatic sea level highstand in the tropical Pacific Ocean. Atolls have been occupied since stable islets formed during the last two millennia. Rising global sea level will impact atoll environments adversely for continued habitation once ambient high-tide level rises above the mid-Holocene low-tide level. That crossover will submerge the resistant paleoreef flats that underpin stable atoll islets and subject their unconsolidated sediment cover to incessant wave attack before ambient sea level actually overtops the islets.

\section{INTRODUCTION}

Pre-industrial peoples managed to live in many marginal environments-the fringe of the desert, the edge of Arctic ice, or the uphill limit of mountain vegetation-but none more marginal than the nearly seamless blend of land and sea on Pacific atolls, where surfaces of reef islets are generally $<3 \mathrm{~m}$ above mean sea level.

The isolated atoll environment (Fig. 1) seems timeless, but this impression is misleading. Atolls have been habitable for no more than one or two millennia, and their future viability for human occupation may be limited to centuries or only decades in the face of rising global sea level. This paper reviews evidence for the past evolution of intra-Pacific atolls, and of the carbonate platforms they cap, and then considers their likely future evolution.

\section{PACIFIC ATOLL PROVINCES}

Atolls are spread across the tropical Pacific Ocean for $9000 \mathrm{~km}$ (Fig. 2), twice the width of the conterminous United States and equivalent to the distance across Eurasia from Great Britain to Korea. Although there are $>175$ Pacific atolls and isolated coral islets, their net land area is only $1800 \mathrm{~km}^{2}$ (less than half the size of Rhode Island), and their total population is only 180,000 (average of $100 / \mathrm{km}^{2}$ ). Areas of central lagoons are two to three orders of magnitude larger than the combined areas of girdling islets, and the largest lagoons are comparable in size to the land area of all Pacific atoll islets combined.

Atolls developed atop carbonate platforms grown on sinking volcanic edifices (Darwin, 1842). Built either as hotspot chains or at isolated volcanic centers on the Pacific plate, these

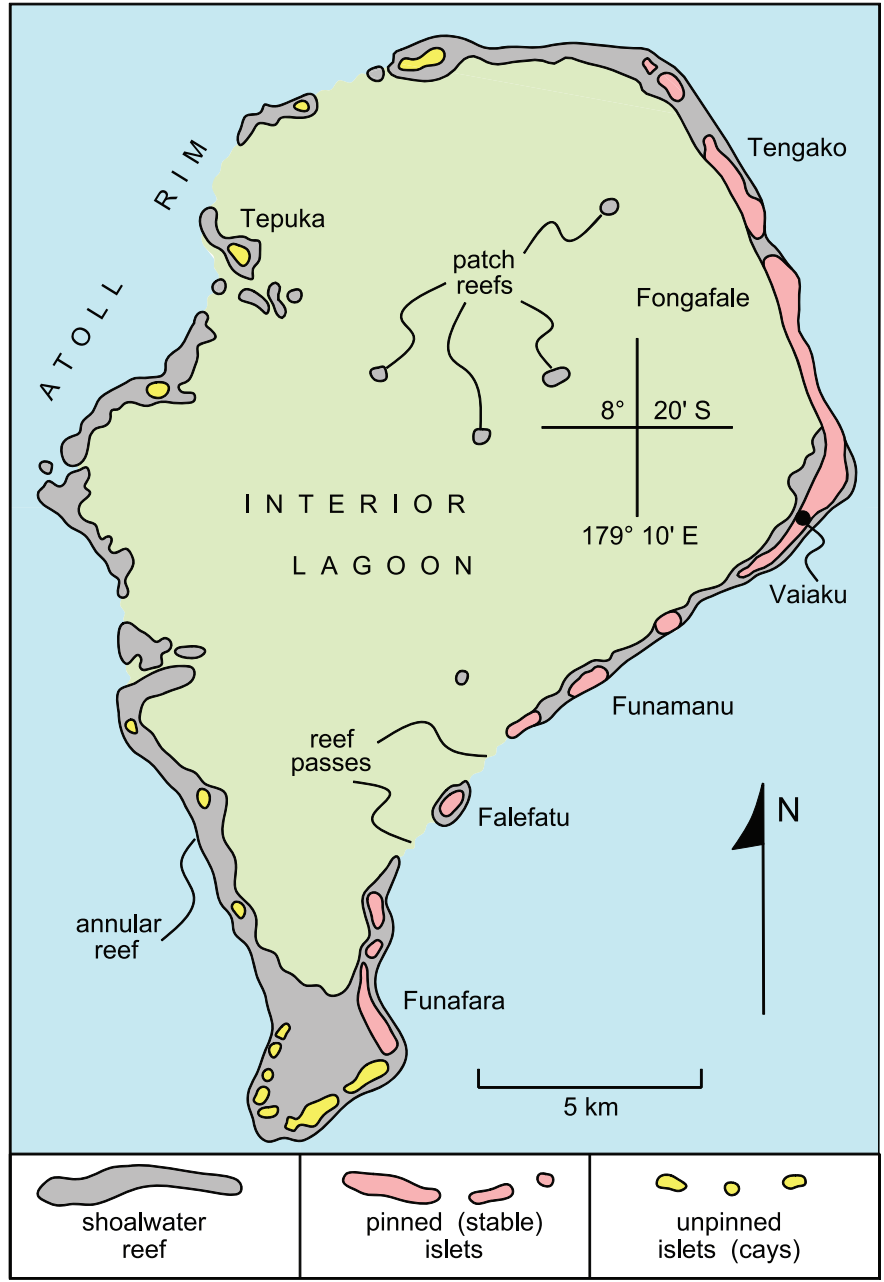

Figure 1. Configuration of the classic atoll of Funafuti (David and Sweet, 1904) in Tuvalu after Dickinson (1999).

edifices subsided as oceanic lithosphere progressively cooled (Scott and Rotondo, 1983a, 1983b). The occurrence of almostatolls (Davis, 1920), where volcano remnants rise from central lagoons surrounded by barrier reefs of atoll dimensions, encouraged an erroneous supposition, first advanced by Darwin (1842) and later developed in detail by Davis (1928). They posited that atoll reefs grew upward from antecedent fringing reefs formed along the shorelines of foundering islands as they sank within an ocean basin maintaining stable sea level. Daly (1910) first noted, however, that the hypothesis linking ancestral fringing reefs to descendant atoll reefs was not viable because stable sea level was not maintained during Quaternary glacial-interglacial fluctuations. Darwin, working and writing at a time before the Agassiz arguments for Pleistocene glaciation had been advanced, was unaware of inherent fluctuations in Quaternary sea level. The geologic history of atolls is more complex than Darwin and Davis envisioned. 


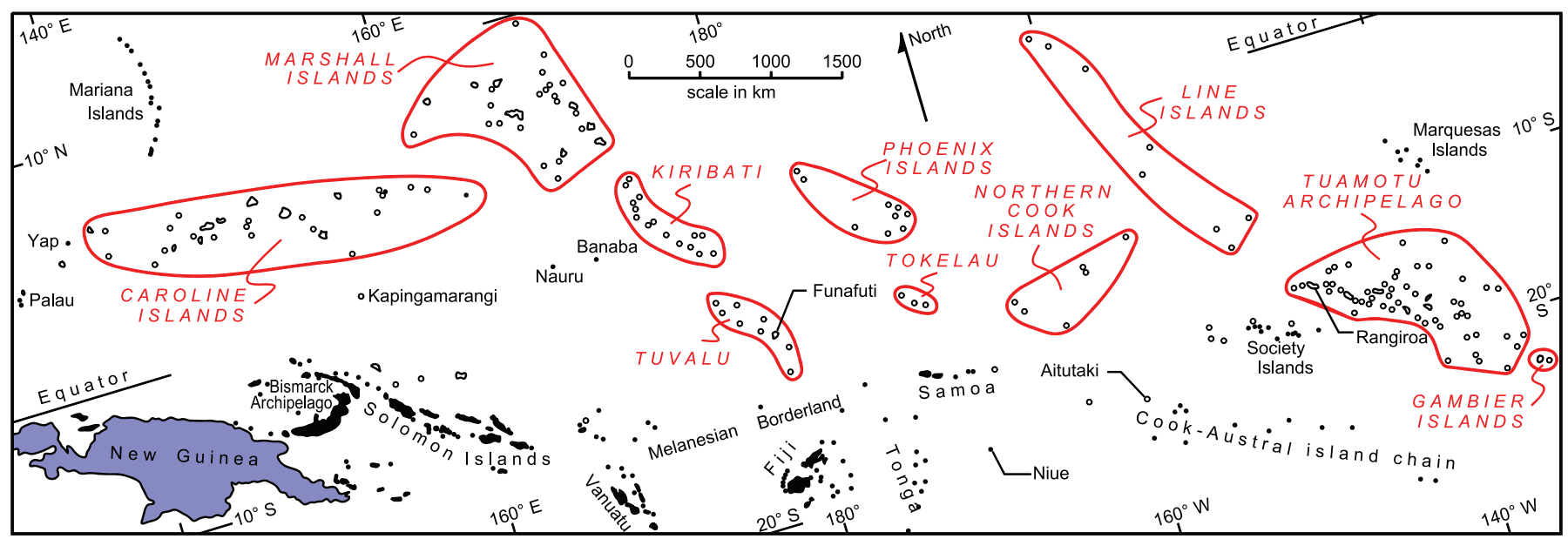

Figure 2. Atoll provinces (in red) of the tropical Pacific Ocean. Open symbols are largely atolls and almost-atolls but also include low-lying reef islands capping table reefs that lack enclosed lagoons. Solid symbols are high islands of volcanic or tectonic origin, including uplifted limestone islands. Islands and atolls too small to show at true scale are shown arbitrarily as solid or open circles.

\section{SYNGLACIAL ATOLL EMERGENCE}

At the peak of the last glaciation, eustatic sea level dropped $120 \mathrm{~m}$ below modern sea level (Peltier, 2002), but the deepest atoll lagoon floors lie $<85 \mathrm{~m}$ below modern sea level, with mean-modal-median depths in the range of 20-36 m (Purdy and Winterer, 2001, 2006; Vecsei, 2003). Carbonate platforms now capped by atolls formed emergent limestone plateaus that rose abruptly above the synglacial sea surface like flotillas of giant ships (Fig. 3). Their paleotopography can be gauged from the configurations of emergent paleoatolls uplifted along the forebulges of modern trenches. For example, the uplifted limestone island of Niue (Fig. 2), on the forebulge of the Tonga Trench, has an oval area of $\sim 260 \mathrm{~km}^{2}$ composed principally of a flat interior plateau (paleolagoon floor) at an elevation of $30-40 \mathrm{~m}$ surrounded by an annular ridge at an elevation of 55-65 m, formed by the Pliocene Mutulau paleoreef (Dickinson, 2001).

Holocene atoll reefs began to grow upward disconformably above the degraded surfaces of last-interglacial reefs during the interval 9-8 ka, when postglacial eustatic sea level, which began rising ca. $19 \mathrm{ka}$ (Clark et al., 2004), first overtopped the gradually drowning limestone plateaus (Figs. 4A and $4 \mathrm{~B})$. The Holocene reefs reach thicknesses of $14 \pm 4 \mathrm{~m}$ beneath the seven Pacific atoll rims and barrier reefs that have been cored (Dickinson, 2004).

The annular shape of atoll reefs is not inherited from predecessor fringing reefs, but stems from the saucer profile (Fig. 4A) of emergent carbonate platforms subject to solution weathering during subaerial exposure (MacNeill, 1954). Analogous topography has been described from modern Pacific islands where highstanding solution ramparts are present along the rims of limestone plateaus and emergent coral terraces (Hoffmeister and Ladd, 1945; Flint et al., 1953; Cloud et al., 1956; Tracey et al., 1964). As noted by Purdy and Winterer (2001), the fundamental morphology of atolls and their lagoons is "solution determined rather than growth predicated" (p. 137).

\section{MID-HOLOCENE HIGHSTAND}

There is yet another crucial aspect of atoll evolution. As eustatic sea level rose during early Holocene time, growing atoll reefs kept pace or caught up with ambient low-tide levels to construct reef flats standing at elevations of $1.0-2.4 \mathrm{~m}$ above modern low-tide level at the time of the mid-Holocene hydro-isostatic highstand in tropical Pacific sea level (Dickinson, 2004). Figure 5 shows areal variations in the magnitude of the highstand within Pacific atoll provinces based on

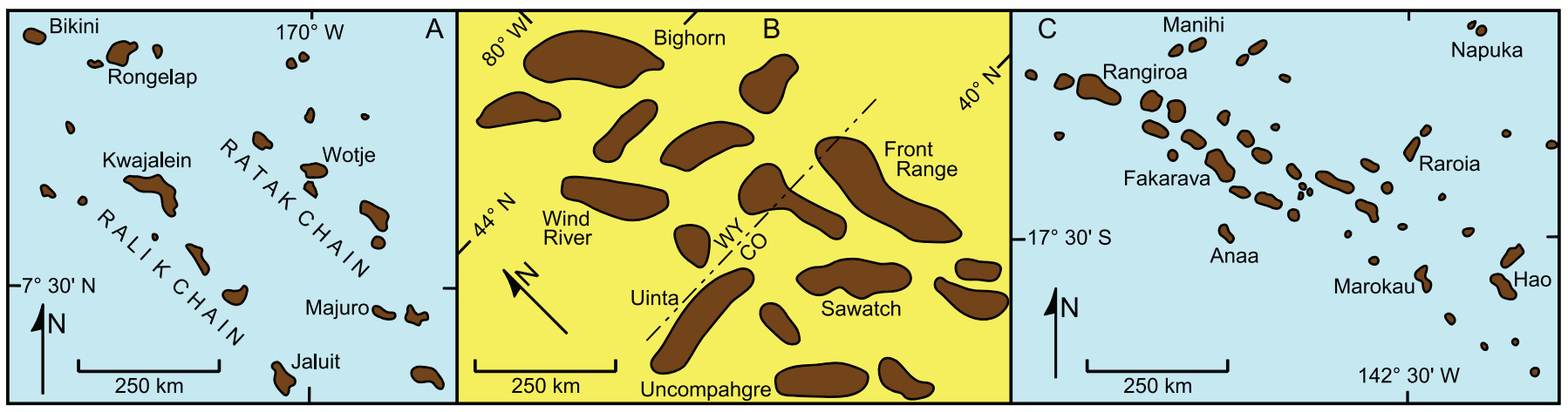

Figure 3. Emergent synglacial limestone plateaus (brown) of the Marshall Islands (A) and Tuamotu Archipelago (C); to convey a graphic sense of their immense geographic extent, Paleogene Laramide uplifts (brown) of the Colorado (CO)-Wyoming (WY) Rocky Mountains (B) are shown at the same scale. 


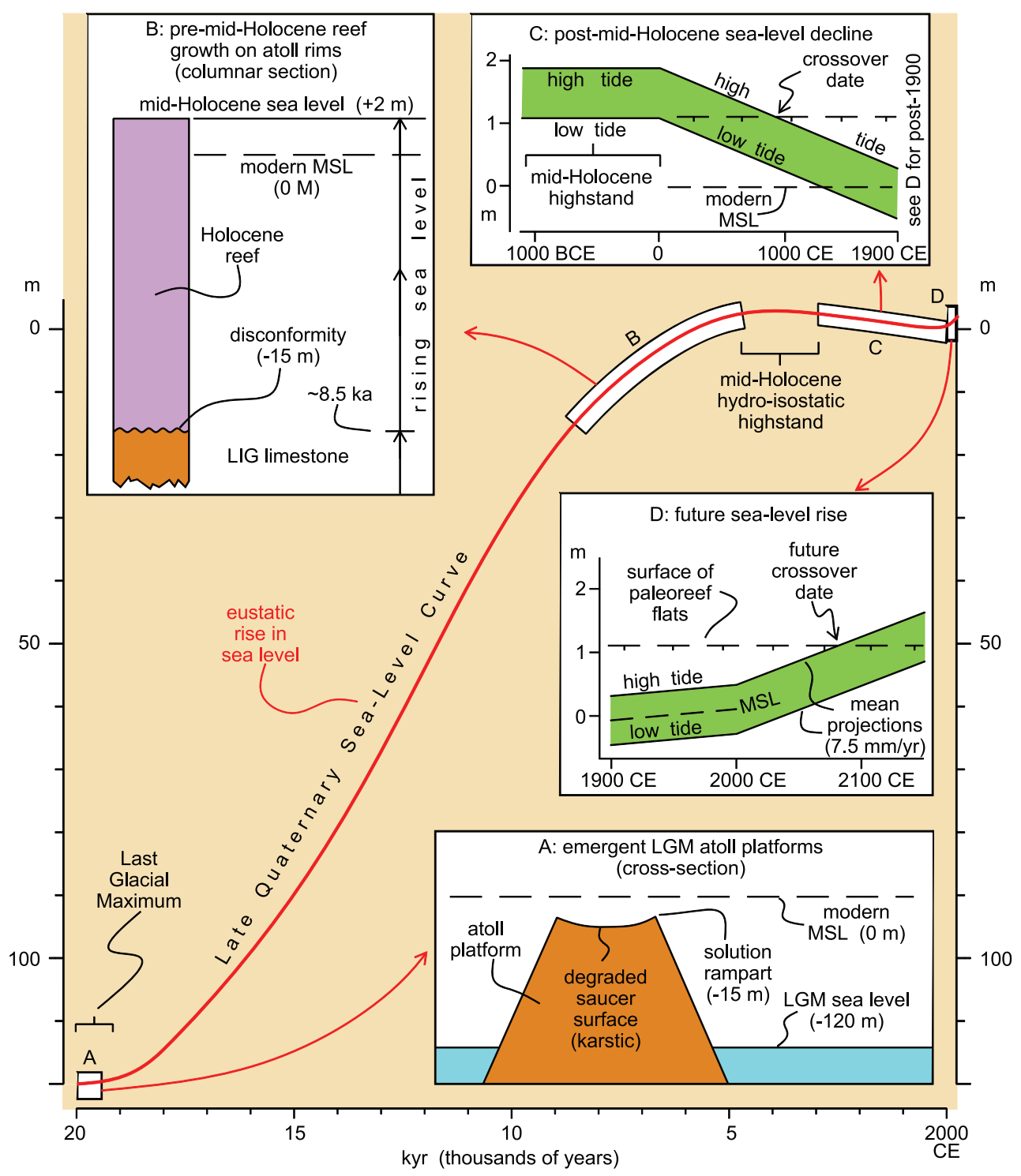

Figure 4. Late Quaternary sea-level curve for tropical Pacific islands (red line) and synoptic effects of changing sea level on atoll evolution (insets). (A) Atoll platforms emergent as subaerial limestone plateaus at Last Glacial Maximum (LGM). (B) Growth of Holocene reef limestone on atoll rims after rising eustatic sea level overtopped the degraded surfaces of Last Interglacial (LIG) paleoreefs (upward limit of reef growth at low-tide level of mid-Holocene hydroisostatic highstand in regional sea level). (C) Post-mid-Holocene decline in sea level carries ambient high-tide level below midHolocene low-tide level (crossover date), fostering the nucleation of stable atoll islets on resistant underpinnings of emergent mid-Holocene paleoreef flats. (D) Projected rise in sea level during continued global warming to carry ambient high-tide level above mid-Holocene low-tide level (overtopping mid-Holocene paleoreef flats at crossover date), thereby allowing fairweather wave attack on unconsolidated sediment cover of atoll islets. Scale origins: elevation (m): 0 - modern mean sea level (MSL); time (kyr): 0-2000 CE.

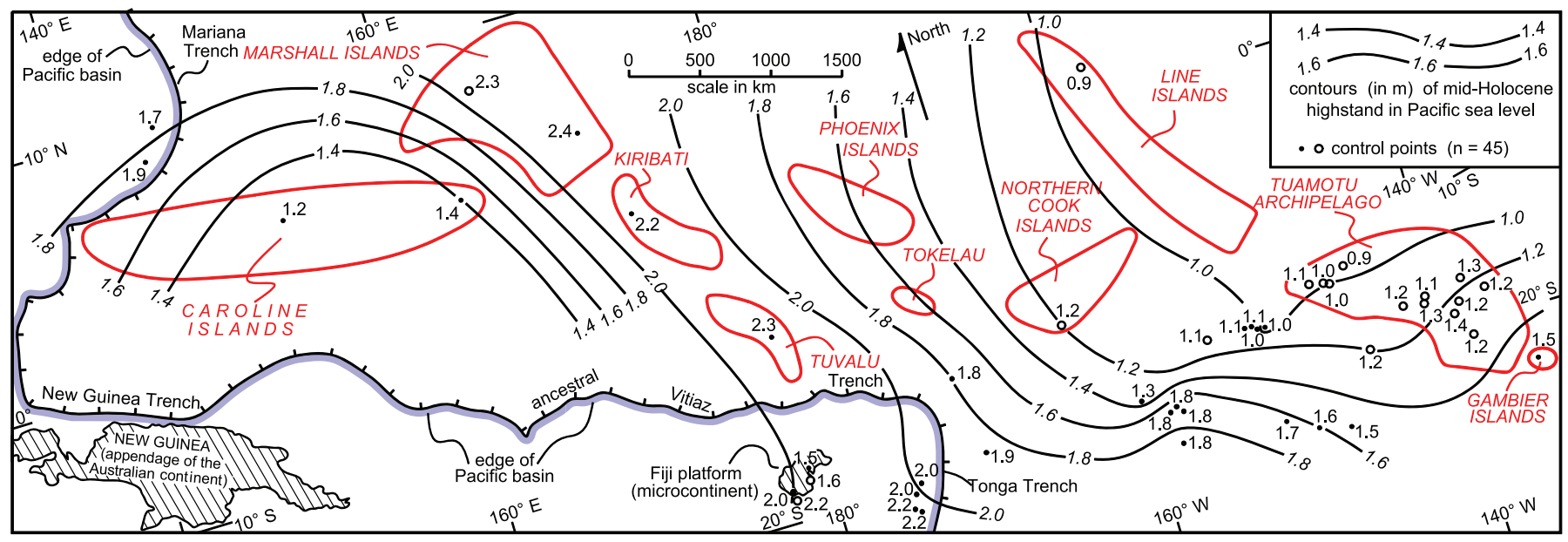

Figure 5. Contours of the magnitude (above modern sea level) of the hydro-isostatic mid-Holocene highstand in regional sea level across the tropical Pacific Ocean; solid dots are control points (number $[n]=27$ ) from personal observations (Dickinson, 1998, 1999, 2000, 2001, 2003; Dickinson et al., 1999; Dickinson and Burley, 2007), and open dots are congruent control points $(n=18)$ from others (Pirazzoli and Montaggioni, 1986, 1988; Nunn, 1988, 2000; Woodroffe et al., 1990; Woodroffe and McLean, 1998; Grossman et al., 1998). For contouring, control points within the microcontinental Fiji platform were ignored from the perspective that isostatic upflexure of the platform under the enhanced load of deepening water offshore promoted emergence that partly counteracted sea-level rise (Nakada, 1986). 
empirical observations of the elevations of mid-Holocene paleoreef remnants above modern reef flats. An axis of maximum highstand transected atoll provinces along the MarshallKiribati (Tongaru)-Tuvalu-Tonga axis, with highstand minima to both the east and west.

The tropical highstand in sea level was a facet of global isostatic adjustment, through slow mantle flowage, to the transfer of mass from circumpolar Pleistocene ice sheets to the Holocene oceans (Dickinson, 2001). Drawdown in tropical Pacific sea level by equatorial ocean siphoning (Mitrovica and Peltier, 1991) transferred the seawater required to cover (a) collapsing submarine arches that had surrounded the surficial loads of ice sheets at high latitudes, and (b) deepening continental shelves that downflexed under the load of augmented meltwater offshore (Mitrovica and Milne, 2002). The theoretical peak of the highstand was $4 \mathrm{ka}$, but the secular crest of the highstand was broad, and sea levels empirically indistinguishable from highstand conditions persisted locally until ca. $2 \mathrm{ka}$ (Dickinson, 2003). Areal variations in the timing of highstand termination (Table 1 ) presumably reflect varying mantle properties, such as those associated with the South Pacific superswell (McNutt and Judge, 1990), but are not presently well understood. The post-highstand decline in regional sea level was essentially monotonic and linear (Chappell, 1983; Woodroffe et al., 2000), although available data cannot preclude minor late Holocene fluctuations in sea level superimposed on the dominant secular trend.

\section{TIDAL CROSSOVER DATE}

During the highstand, atoll reefs were largely awash, although some transient sand cays may have been thrown up by wave action along the circumferential trends of the annular reef flats. As late Holocene sea level declined at Pacific atolls, however, ambient high tide eventually fell below the surfaces of paleoreef flats constructed at mid-Holocene low-tide level (Fig. 4C). After that crossover date (Dickinson, 2003), which varied from one atoll cluster to another (Table 1), islets could be constructed by wave action atop remnant paleoreef flats underlain by cemented reef limestone resistant to wave attack. Islets of this type, blanketed by unconsolidated surficial sediment emplaced by storm washover but underpinned by solid foundations, are termed pinned islets (Dickinson, 2004). These are the stable islets of atolls because they are held in place by firm paleoreef underpinnings that gird their flanks from wave attack (Dickinson, 1999). Transient sand cays that lack underpinnings of mid-Holocene paleoreef flats shift their positions and morphology in irregular patterns under both fair-weather and storm-wave attack on atoll reefs (Richmond, 1992).

Pinned islets are consistently most prevalent on the eastern flanks of atoll rims (Fig. 1), facing the prevailing trade winds of the tropical Pacific. Reef growth is more vigorous along the windward rims of atolls, where reefs are pervasively bathed by wind-driven seawater richer in nutrients than the more stagnant seawater contacting leeward atoll rims. Emergent remnants of mid-Holocene paleoreef flats are consequently more extensive and support more pinned islets along the windward eastern sides of most atolls. The relict reef flats inherited from the mid-Holocene highstand are of signal importance for the existence of stable atoll islets.

Crossover dates for each atoll province can be inferred from local magnitudes of the mid-Holocene highstand, the times of its effective termination, and local tidal ranges (Table 1), but generally fall within the interval 500-1000 CE. Human settlement of atolls was typically delayed until after the crossover date, when stable islets could form on atoll rims (Dickinson, 2003), and atolls have generally not been occupied for more than 1000-1500 yr.

TABLE 1. INFERRED CROSSOVER DATES FOR PACIFIC ATOLL CLUSTERS*

\begin{tabular}{|c|c|c|c|c|c|c|}
\hline Atoll cluster ${ }^{\dagger}$ & $\begin{array}{l}\text { highstand } \\
\text { magnitude } \\
(\mathrm{m})\end{array}$ & $\begin{array}{l}\text { highstand } \\
\text { termination }^{\#} \\
(\mathrm{BCE} \text { or } \mathrm{CE})\end{array}$ & $\begin{array}{c}\text { tidal range } \\
(\mathrm{m})\end{array}$ & $\begin{array}{c}\text { past crossover } \\
\text { date** } \\
(\mathrm{CE}) \\
\end{array}$ & $\begin{array}{c}\text { earliest future } \\
\text { crossover date }^{\dagger \dagger} \\
\text { (CE) }\end{array}$ & $\begin{array}{c}\text { latest future } \\
\text { crossover date }^{\S \S} \\
(\mathrm{CE})\end{array}$ \\
\hline western Caroline Islands & 1.6 & $100 \mathrm{CE}$ & 1.2 & 400 & 2050 & 2100 \\
\hline central Caroline Islands & 1.2 & $100 \mathrm{BCE}$ & 0.6 & 500 & 2060 & 2120 \\
\hline eastern Caroline Islands & 1.4 & $200 \mathrm{BCE}$ & 0.9 & 600 & 2050 & 2100 \\
\hline Marshall Islands & 2.4 & $600 \mathrm{BCE}$ & 1.6 & 700 & 2080 & 2160 \\
\hline Kiribati-Tungaru chain & 2.2 & $300 \mathrm{BCE}$ & 1.5 & 1000 & 2070 & 2140 \\
\hline Tuvalu & 2.3 & $200 \mathrm{BCE}$ & 1.6 & 1100 & 2070 & 2140 \\
\hline Tokelau & 1.8 & $100 \mathrm{BCE}$ & 1.0 & 1000 & 2080 & 2160 \\
\hline Phoenix Islands & 1.7 & $100 \mathrm{BCE}$ & 1.0 & 900 & 2070 & 2140 \\
\hline northern Cook Islands & 1.1 & $400 \mathrm{CE}$ & 0.6 & 900 & 2050 & 2100 \\
\hline Line Islands (Kiritimati) & 0.9 & $300 \mathrm{CE}$ & 0.4 & 800 & 2050 & 2100 \\
\hline northern Tuamotu Archipelago & 1.0 & $500 \mathrm{CE}$ & 0.3 & 900 & 2070 & 2140 \\
\hline Society Islands (Tupai) & 1.0 & $100 \mathrm{BCE}$ & 0.3 & 500 & 2070 & 2140 \\
\hline southern Tuamotu Archipelago & 1.2 & $600 \mathrm{CE}$ & 0.4 & 900 & 2080 & 2160 \\
\hline Gambier Archipelago (Temoe) & 1.5 & $300 \mathrm{CE}$ & 0.7 & 900 & 2070 & 2140 \\
\hline Cook-Austral chain (Aitutaki) & 1.3 & $200 \mathrm{BCE}$ & 0.8 & 800 & 2050 & 2100 \\
\hline \multicolumn{7}{|c|}{$\begin{array}{l}\text { Note: } \mathrm{BCE}-\text { before common era; } \mathrm{CE}-\text { common era. } \\
\text { *All elevations } \pm 0.1 \mathrm{~m} \text { (observational uncertainty) and past dates } \pm 100+\mathrm{yr} \text { (owing to sparse age control and/or uncertainties } \\
\text { in radiocarbon calibrations). } \\
\text { †See Figure } 2 \text { for location (islands in parentheses are relevant individual atolls or almost-atolls). } \\
{ }^{\S} \text { From Figure } 5 \text {. } \\
{ }^{\#} \text { Adapted from Dickinson (2003). } \\
\text { **Date when declining high tide fell below paleoreef flats built to mid-Holocene low-tide level (adapted from Dickinson, } 2003 \text { ) } \\
{ }_{\dagger}^{\dagger} \text { Date when rising high tide will submerge mid-Holocene paleoreef remnants if global sea level rises } \sim 1.0 \mathrm{~m} \text { by } 2100 \mathrm{CE} \text {. } \\
{ }_{\S} \text { Date when rising high tide will submerge mid-Holocene paleoreef remnants if global sea level rises only } \sim 0.5 \mathrm{~m} \text { by } 2100 \mathrm{CE} \\
\text { (and continues to rise thereafter at the same rate). } \\
\# \text { Data interpolated from neighboring island groups (no internal data available). }\end{array}$} \\
\hline
\end{tabular}


This insight was initially advanced by Pirazzoli and Montaggioni (1986) for the Tuamotu Archipelago, which they judged could not have been occupied before $800 \mathrm{CE}$. Archaeological investigations elsewhere have shown that human occupation of the almost-atoll of Aitutaki (Fig. 2) in the southern Cook Islands was delayed until as late as 1200 CE (Allen and Wallace, 2007), and there is no robust evidence for occupation of the atolls in the northern Cook Islands any earlier (Dickinson, 2003). The oldest known habitation sites in Tuvalu (Dickinson et al., 1990) and Tokelau (Best, 1988) similarly date from ca. 1000 CE. However, radiocarbon ages for cultural sites date back to the first millennium CE for multiple atolls in the Marshall Islands (see references in Dickinson, 2003). The somewhat earlier occupation of the Marshall Islands may have been promoted by the comparatively large local tidal range (Table 1), allowing for pre-crossover emergence of mid-Holocene paleoreef flats to elevations high enough above ambient low-tide levels to foster nucleation of habitable atoll islets.

\section{RISING SEA LEVEL}

During the twentieth century, global sea level rose at a persistent mean rate of $1.7-1.9 \mathrm{~mm} / \mathrm{yr}$ (Douglas, 1997) due to combined eustatic and steric effects (Miller and Douglas, 2004). If we assume that the indicated rate of sea-level rise has persisted since the onset of global warming ca. 1908 (Jones et al., 1999), the aggregate rise over the past century can be hindcast as $180 \mathrm{~mm}$. Satellite altimetry suggests that the rate increased to $\sim 2.5 \mathrm{~mm} / \mathrm{yr}$ over the last decade of the twentieth century and to $\sim 4 \mathrm{~mm} / \mathrm{yr}$ during the first decade of the present century (Beckley et al., 2007), but continued satellite observations are required to distinguish a lasting secular trend from a transient effect. A steady rise in sea level at $\sim 2.5 \mathrm{~mm} / \mathrm{yr}$ might have been maintained, however, through the whole latter half of the twentieth century, were it not for the impoundment of water in artificial reservoirs on land (Chao et al., 2008). In any case, the increase in the rate of sea-level rise over the past $15 \mathrm{yr}$ would sum to only an additional $20 \mathrm{~mm}$ of net rise, for an aggregate of $200 \mathrm{~mm}$ over the past century. This centennial trend in past global sea level cannot readily be detected on shorelines of Pacific islands because of (a) seasonal fluctuations of 100$200 \mathrm{~mm}$ in local sea level as trade winds wax and wane, and (b) multi-annual fluctuations of as much as $500 \mathrm{~mm}$ in regional sea level between El Niño and La Niña phases of the Southern Oscillation (Cane, 2005) as episodic shifts in prevailing winds blow seawater back and forth across the ocean basin (Sherwood and Howorth, 1996).

If continued long enough or enhanced by further global warming, a future rise in sea level is a clear threat to atoll dwellers (Roy and Connell, 1991). Forecasts of future global sea levels are inherently uncertain, but a postulated sea-level rise in the range of $0.5-1.0 \mathrm{~m}$ by the year 2100 is the most likely estimate based on various studies (Raper and Braithwaite, 2006; Rahmstorf, 2007; Meier et al., 2007; Pfeffer et al., 2008). This range of projected change in sea level would carry ambient high tide above midHolocene low tide at most atolls, in effect producing another crossover date from rising rather than falling sea level (Fig. 4D). The indicated crossover dates (Table 1) are in the latter half of this century (2050-2080 CE) for rapid future rise in sea level
( $10 \mathrm{~mm} / \mathrm{yr}$ ) or in the first half of the next century (2100-2160 CE) for a slower net rate of rise $(\sim 5 \mathrm{~mm} / \mathrm{yr})$. Projection of the historic rate of sea-level rise $(\leq 2.5 \mathrm{~mm} / \mathrm{yr})$ into the future would delay the crossover date until $2200 \mathrm{CE}$ or later, but persistence of the past rate of sea-level rise cannot be expected unless extant predictions of accelerating sea-level rise from enhanced global warming are invalid.

After the future crossover date, stable pinned islets composed of unconsolidated sand resting on the remnant surfaces of inherited mid-Holocene paleoreef flats will be exposed to potentially devastating fair-weather wave attack (Dickinson, 1999). Flanking buttresses formed by the erosional edges of the cemented paleoreef flats protect the islet interiors from surf except during hurricanes and cyclones with strong waves and high storm surges, but their shielding would be lost once paleoreef flats are submerged. Stable islets might thus be destroyed by wave attack long before rising sea level ever overtops their surfaces.

The projected future crossover dates in Table 1 provide a provisional basis for gauging when higher sea levels may become an existential threat to atoll dwellers. Given substantive uncertainties in future forecasts for global sea level, the inferred dates must be regarded as indicative rather than conclusive. Even so, prudence dictates that contingency planning should begin soon for atoll populations potentially at risk from rising sea level. Adaptation to changing conditions may eventually become infeasible on many atolls.

\section{CONCLUSIONS}

The annular Holocene reefs of modern intra-Pacific atolls grew during the past 8-9 ka after rising postglacial eustatic sea level overtopped the degraded remnants of last-interglacial reefs exposed to subaerial weathering during the last glaciation. Raised atoll rims do not reflect the upward growth of ancient fringing reefs surrounding volcanic islands that have subsided beneath atoll lagoons, but were produced as solution ramparts rimming carbonate platforms exposed to the atmosphere during synglacial drawdowns in sea level. A midHolocene hydro-isostatic highstand in tropical Pacific sea level drowned atoll rims and built reef flats above modern sea level. Human occupation of most atolls was delayed until ambient high tide fell below the mid-Holocene low-tide level. After that crossover date, stable atoll islets formed with underpinnings of resistant mid-Holocene paleoreef flats to protect the flanks of the islets from wave attack. If rising future sea level overtops the mid-Holocene reef remnants, atoll islets will become subject to enhanced erosion long before sea level overtops the surfaces of the islets. My hazard analysis underscores the importance of understanding the geomorphic history of atolls for estimating the risks associated with a rise in sea level during future global warming.

\section{ACKNOWLEDGMENTS}

Preparation of this paper was suggested by Warren Hamilton, and Jim Abbott of Scigraphics prepared the figures. All field work was done in company with Jacqueline Dickinson and numerous island residents. Discussions with J.E. Spencer and reviews by E.L. Winterer and R.N. Ginsburg are much appreciated. Both text and figures were improved by editorial recommendations of Stephen T. Johnston. 


\section{REFERENCES CITED}

Allen, M.S., and Wallace, R., 2007, New evidence from the East Polynesian gateway: Substantive and methodological results from Aitutaki, southern Cook Islands: Radiocarbon, v. 49, p. 1163-1179.

Beckley, B.D., Lemoine, F.G., Luthcke, S.B., Ray, R.D., and Zelensky, N.P., 2007, A reassessment of global and regional mean sea level trends from TOPEX and Jason- 1 altimetry based on revised reference frame and orbits: Geophysical Research Letters, v. 34, p. L14608, doi: 10.1029/2007GL030002.

Best, S., 1988, Tokelau archaeology: A preliminary report of an initial survey and excavations: Indo-Pacific Prehistory Association Bulletin, v. 8, p. 104-118.

Cane, M.A., 2005, The evolution of El Niño, past and future: Earth and Planetary Science Letters, v. 230, p. 227-240, doi: 10.1016/j. epsl.2004.12.003.

Chao, B.F., Wu, Y.H., and Li, Y.S., 2008, Impact of artificial reservoir water impoundment on global sea level: Science, v. 320, p. 212-214, doi: 10.1126/science.1154580.

Chappell, J., 1983, Evidence for smoothly falling sea levels relative to north Queensland, Australia during the past 6,000 years: Nature, v. 302, p. 406-408, doi: 10.1038/302406a0.

Clark, P.U., McCabe, A.M., Mix, A.C., and Weaver, A.J., 2004, Rapid rise of sea level 19,000 years ago and its global implications: Science, v. 304, p. 1141-1144, doi: 10.1126/science.1094449.

Cloud, P.E., Jr., Schmidt, R.G., and Burke, H.W., 1956, Geology of Saipan, Mariana Islands; Part I: General geology: U.S. Geological Survey Professional Paper 280-A, 126 p.

Daly, R.A., 1910, Pleistocene glaciations and the coral reef problem: American Journal of Science [ser. 4], v. 30, p. 297-308.

Darwin, C., 1842, The structure and distribution of coral reefs: London, Smith Elder, $332 \mathrm{p}$

David, T.W.E., and Sweet, G., 1904, The geology of Funafuti: The atoll of Funafuti: Borings into a coral reef and the results: London, Royal Society, p. 61-124.

Davis, W.M., 1920, The small islands of almost-atolls: Nature, v. 105, p. 292-293, doi: 10.1038/105292b0.

Davis, W.M., 1928, The coral reef problem: New York, American Geographical Society Special Paper No. 9, 596 p.

Dickinson, W.R., 1998, Geomorphology and geodynamics of the CookAustral island-seamount chain in the South Pacific Ocean: Implications for hotspots and plumes: International Geology Review, v. 40, p. 1039-1075.

Dickinson, W.R., 1999, Holocene sea-level record on Funafuti and potential impact of global warming on central Pacific atolls: Quaternary Research, v. 51, p. 124-132, doi: 10.1006/qres.1998.2029.

Dickinson, W.R., 2000, Hydro-isostatic and tectonic influences on emergent Holocene paleoshorelines in the Mariana Islands, western Pacific Ocean: Journal of Coastal Research, v. 16, p. 735-746.

Dickinson, W.R., 2001, Paleoshoreline record of relative Holocene sea levels on Pacific islands: Earth-Science Reviews, v. 55, p. 191-234, doi: 10.1016/S0012-8252(01)00063-0.

Dickinson, W.R., 2003, Impact of mid-Holocene hydro-isostatic highstand in regional sea level on habitability of islands in Pacific Oceania: Journal of Coastal Research, v. 19, p. 489-502.

Dickinson, W.R., 2004, Impacts of eustasy and hydro-isostasy on the evolution and landforms of Pacific atolls: Palaeogeography, Palaeoclimatology, Palaeoecology, v. 213, p. 251-269.

Dickinson, W.R., and Burley, D.V., 2007, Geoarchaeology of Tonga: Geotectonic and geomorphic controls: Geoarchaeology, v. 22, p. 229-259, doi: 10.1002/gea.20164.

Dickinson, W.R., Takayama, J., Snow, E.A., and Shutler, R., Jr., 1990, Sand temper of probable Fijian origin in prehistoric potsherds from Tuvalu: Antiquity, v. 64, p. 307-312.

Dickinson, W.R., Burley, D.V., and Shutler, R., Jr., 1999, Holocene paleoshoreline record in Tonga: Geomorphic features and archaeological implications: Journal of Coastal Research, v. 15, p. 682-700.
Douglas, B.C., 1997, Global sea level rise: A redetermination: Surveys in Geophysics, v. 18, p. 279-292, doi: 10.1023/A:1006544227856.

Flint, D.E., Corwin, G., Dings, M.G., Fuller, W.P., MacNeill, F.S., and Saplis, R.A., 1953, Limestone walls of Okinawa: Geological Society of America Bulletin, v. 64, p. 1247-1260, doi: 10.1130/0016-7606 (1953)64[1247:LWOO]2.0.CO;2.

Grossman, E.E., Fletcher, C.H., III, and Richmond, B.M., 1998, The Holocene sea-level highstand in the equatorial Pacific: Analysis of the insular paleosea-level database: Coral Reefs, v. 17, p. 309-327, doi: 10.1007/ s003380050132.

Hoffmeister, J.E., and Ladd, H.S., 1945, Solution effects on elevated limestone terraces: Geological Society of America Bulletin, v. 56, p. 809-818, doi: 10.1130/0016-7606(1945)56[809:SEOELT]2.0.CO;2.

Jones, P.D., New, M., Parker, D.E., Martin, S., and Rigor, D.E., 1999, Surface air temperature and its changes over the past 150 years: Reviews of Geophysics, v. 37, p. 173-199, doi: 10.1029/1999RG900002.

MacNeill, F.S., 1954, The shape of atolls: An inheritance from subaerial erosion forms: American Journal of Science, v. 252, p. 402-427.

McNutt, M., and Judge, A.V., 1990, The superswell and mantle dynamics beneath the South Pacific: Science, v. 248, p. 969-975, doi: 10.1126/ science.248.4958.969.

Meier, M.F., Dyurgerov, M.B., Rick, U.K., O'Neel, S., Pfeffer, W.T., Anderson, R.S., Anderson, S.P., and Glazovsky, A.F., 2007, Glaciers dominate eustatic sea-level rise in the 21st century: Science, v. 317, p. 1064-1067, doi: 10.1126/science.1143906.

Miller, L., and Douglas, B.C., 2004, Mass and volume contributions to twentieth-century global sea level rise: Nature, v. 428, p. 406-409, doi: 10.1038/nature02309.

Mitrovica, J.X., and Milne, G.A., 2002, On the origin of late Holocene sealevel highstands within equatorial ocean basins: Quaternary Science Reviews, v. 21, p. 2179-2190, doi: 10.1016/S0277-3791(02)00080-X.

Mitrovica, J.X., and Peltier, W.R., 1991, On postglacial geoid subsidence over the equatorial oceans: Journal of Geophysical Research, v. 96, p. 20,053-20,071, doi: 10.1029/91JB01284.

Nakada, M., 1986, Holocene sea levels on oceanic islands: Implications for the rheological structure of the Earth's mantle: Tectonophysics, v. 121, p. 263-276, doi: 10.1016/0040-1951(86)90047-8.

Nunn, P.D., 1988, Vatulele: A study in the geomorphological development of a Fiji island: Suva, Fiji Mineral Resources Department Memoir 2, 99 p.

Nunn, P.D., 2000, Significance of emerged Holocene corals around Ovalau and Moturiki islands, Fiji, southwest Pacific: Marine Geology, v. 163, p. 345-351, doi: 10.1016/S0025-3227(99)00114-0.

Peltier, W.R., 2002, On eustatic sea level history: Last glacial maximum to Holocene: Quaternary Science Reviews, v. 21, p. 377-396, doi: 10.1016/S0277-3791(01)00084-1.

Pfeffer, W.T., Harper, J.T., and O'Neel, S., 2008, Kinematic constraints on glacier contributions to 21 st-century sea-level rise: Science, v. 321, p. 1340-1343, doi: 10.1126/science.1159099.

Pirazzoli, P.A., and Montaggioni, L.F., 1986, Late Holocene sea level changes in the northwest Tuamotu Islands, French Polynesia: Quaternary Research, v. 25, p. 350-368, doi: 10.1016/0033-5894(86)90006-2.

Pirazzoli, P.A., and Montaggioni, L.F., 1988, Holocene sea-level changes in French Polynesia: Palaeogeography, Palaeoclimatology, Palaeoecology, v. 68, p. 153-175, doi: 10.1016/0031-0182(88)90037-5.

Purdy, E.G., and Winterer, E.L., 2001, Origins of atoll lagoons: Geological Society of America Bulletin, v. 113, p. 837-854, doi: 10.1130/00167606(2001)113<0837:OOAL>2.0.CO;2.

Purdy, E.G., and Winterer, E.L., 2006, Contradicting barrier reef relationships for Darwin's evolution of reef types: International Journal of Earth Sciences, v. 95, p. 143-167, doi: 10.1007/s00531-005-0511-2.

Rahmstorf, S., 2007, A semi-empirical approach to projecting future sea-level rise: Science, v. 315, p. 368-370, doi: 10.1126/science.1135456.

Raper, S.C.B., and Braithwaite, R.J., 2006, Low sea level rise projections from mountain glaciers and icecaps under global warming: Nature, v. 439, p. 311-313, doi: 10.1038/nature04448. 
Richmond, B.M., 1992, Development of atoll islets in the central Pacific: Guam, University of Micronesia, 7th International Coral Reef Symposium Proceedings, v. 2, p. 1185-1194.

Roy, P., and Connell, J., 1991, Climatic change and the future of atoll states: Journal of Coastal Research, v. 7, p. 1057-1075.

Scott, G.A.J., and Rotondo, G.M., 1983a, A model for the development of types of atolls and volcanic islands on the Pacific lithospheric plate: Atoll Research Bulletin 260, 33 p.

Scott, G.A.J., and Rotondo, G.M., 1983b, A model to explain the difference between Pacific island-atoll types: Coral Reefs, v. 1, p. 139-150, doi: 10.1007/BF00571191.

Sherwood, A., and Howorth, R., 1996, Coasts of Pacific islands: Suva, Fiji, South Pacific Applied Geosciences Commission (SOPAC) Miscellaneous Report 222, 39 p.

Tracey, J.L., Jr., Schlanger, S.O., Stark, J.T., Doan, D.R., and May, H.G., 1964, General geology of Guam: U.S. Geological Survey Professional Paper 403-A, p. A1-A104.
Vecsei, A., 2003, Systematic yet enigmatic depth distribution of the world's modern warm-weather carbonate platforms: The 'depth window': Terra Nova, v. 15, p. 170-175, doi: 10.1046/j.13653121.2003.00477.x.

Woodroffe, C.D., and McLean, R.F., 1998, Pleistocene morphology and Holocene emergence of Christmas (Kiritimati) Island, Pacific Ocean: Coral Reefs, v. 17, p. 235-248, doi: 10.1007/s003380050124.

Woodroffe, C.D., Stoddart, D.R., Spencer, T., Scoffin, T.P., and Tudhope, A.W., 1990, Holocene emergence in the Cook Islands, south Pacific: Coral Reefs, v. 9, p. 31-39, doi: 10.1007/BF00686719.

Woodroffe, C.D., Kennedy, D.M., Hopley, D., Rasmussen, C.E., and Smithers, S.G., 2000, Holocene reef growth in Torres Strait: Marine Geology, v. 170, p. 331-346, doi: 10.1016/S0025-3227(00)00094-3.

Manuscript received 24 November 2008; accepted 24 December 2008. 3

\section{GSA news and information is ready when you are!}

GSA Connection, GSA's e-newsletter, brings you up-to-the-minute information on GSA programs and events, award nomination deadlines, government and international affairs, new GSA books, media coverage, and job and scholarship opportunities.

- $\quad$ Read this month's issue at www.geosociety.org/GSA_Connection

- $\quad$ Sign up to receive GSA Connection by e-mail at http://rock.geosociety.org/Enews

GSA Today articles are always open-access online-just follow the link at www.geosociety.org/pubs.

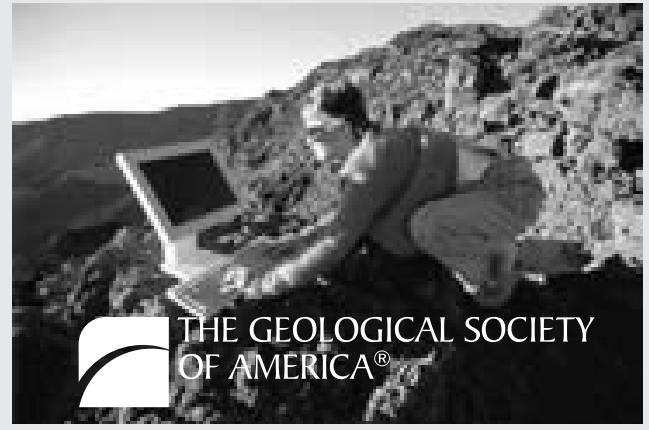

